\title{
Optimization of Operational Parameters and Bath Control for Electrodeposion of Ni-Mo-B Amorphous Alloys
}

\author{
Fabiano A. Marinho, François S. M. Santana, André L. S. Vasconcelos, Renato A. C. Santana \\ and Shiva Prasad*
}

\author{
Departamento de Engenharia Química, Centro de Ciências e Tecnologia, Universidade Federal da Paraíba, \\ CP 10108, 58109-970 Campina Grande-PB, Brazil
}

\begin{abstract}
A otimização de parâmetros operacionais de um processo de eletrodeposição de camada metálica amorfa de liga níquel-molibdênio contendo boro sobre um catodo utilizando um banho de sulfato de níquel, molibdato de sódio, fosfato de boro, citrato de sódio, 1-docecilsulfato de sódio e hidróxido de amônio para pH 9,5 foi estudada. Estudos detalhados sobre o efeito da temperatura do banho, agitação mecânica, densidade de corrente catódica e formato de ânodo conduziu às condições ótimas para obtenção de depósitos de ligas satisfatórias. A mais alta eficiência catódica, cerca de $69 \%$ para ânodo cilíndrico e $64 \%$ para ânodo retengular de platina, foi obtida a $80^{\circ} \mathrm{C}, 15 \mathrm{rpm}$ e $100 \mathrm{~mA} \mathrm{~cm}{ }^{-2}$. Um método voltamétrico para controle e monitoramento automático do processo foi proposto.

Optimization of operational parameters of an electrodeposition process for deposition of boroncontaining amorphous metallic layer of nickel-molybdenum alloy onto a cathode from an electrolytic bath having nickel sulfate, sodium molybdate, boron phosphate, sodium citrate, sodium-1-dodecylsulfate and ammonia for $\mathrm{pH}$ adjustments to 9.5 has been studied. Detailed studies of the efects on bath temperature, mechanical agitation, cathode current density and anode format have led to optimum operational conditions for obtaining satisfactory alloy deposits. The highest cathode current efficiency for deposition of the alloy was about $69 \%$ for cylindrical and $64 \%$ for rectangular platinum anode while working at bath temperature $80^{\circ} \mathrm{C}$, cathode rotation $15 \mathrm{rpm}$ and cathode current density $100 \mathrm{~mA} \mathrm{~cm}^{-2}$. A voltammetric method for automatic monitoring and control of the process was proposed.
\end{abstract}

Keywords: electrodeposition, electrolytic baths, nickel-molybdenum alloys, amorphous alloys

\section{Introduction}

The electrodeposition of molybdenum and tungsten has been of considerable interest because of unusual properties of these metals. ${ }^{1}$ Of all the metals; tungsten possesses the highest melting point $\left(3410^{\circ} \mathrm{C}\right)$, the lowest coefficient of linear thermal expansion $\left(4.3 \times 10^{-6 /} /{ }^{\circ} \mathrm{C}\right)$ and the highest tensile strength $\left(410 \mathrm{~kg} \mathrm{~mm}^{-2}\right)$. It has very high thermal conductivity $\left(0.487 \mathrm{cal} \mathrm{cm}^{-2} / \mathrm{cm} /{ }^{\circ} \mathrm{C}\right)$ and is one of the densest metal $\left(19.3 \mathrm{~g} \mathrm{~cm}^{-3}\right)$. The metal has unusual mechanical properties. The properties of molybdenum are similar to those of tungsten but not as outstanding. Since molybdenum is cheaper than tungsten it is a more economic alternative. For practical applications its most important properties are its high melting point $2610^{\circ} \mathrm{C}$ and its relatively high mechanical strength at elevated temperatures. Its $0.45 \%$ titanium alloy has a tensile strength of

* e-mail: prasad@deq.ufpb.br about $5000 \mathrm{~kg} \mathrm{~cm}^{-2}$ at $870{ }^{\circ} \mathrm{C}$ as compared to about 1000 $\mathrm{kg} \mathrm{cm}^{-2}$ for the so-called superstrength alloys now in use. Molybdenum is more ductile than tungsten. It has low coefficient of linear thermal expansion and high Young's modulus of elasticity. Molybdenum has good resistance to chemical attack; but at elevated temperatures it gets oxidized.

In spite of numerous claims, the electrodeposition of tungsten as well as of molybdenum in pure state from aqueous solutions has been unsuccessful., ${ }^{2,3}$ But their electrolytic induced codeposition occurs with iron-group metals. ${ }^{1}$ The most important of the early researches on the deposition of tungsten- and molybdenum-alloys were those of several Russians, particularly the work of Goltz and Kharlamov. ${ }^{4}$ They used ammoniacal plating solutions. The deposits obtained were porous and weak. The next development was the use of organic hydroxy acids in these ammoniacal baths to yield more stable baths of much higher concentrations. ${ }^{5,6}$ The alloys deposited were crystalline. 
More recently Watanabe ${ }^{7}$ has reported electrodeposition of several amorphous alloys.

Literature reveals that under proper conditions of bath composition, voltage and current parameters, an amorphous layer may be formed on a cathode by electrodeposition. But, for the most of this studies, the electrodeposition of amorphous alloys of these metals has been limited to a few demonstration systems of little direct practical interest, and there are no known instances of electrodeposition of high hardness, wear resistance, moderately ductile amorphous alloys. If a technique could be found to produce such materials it would then be possible, for example, to produce highly wear-resistant barrel liners by replacing conventional low-ductility chromium liner coating with an amorphous layer that would resist spalling of the coating. Many other such applications may be envisioned, including, for example, pump housing, instrument bores, piston rings, cylinder housing and bearings.

Thus there is a need for a process for preparing coatings of high hardness, wear-resistant, corrosion resistant and moderately ductile amorphous alloys by electrodeposition. The work on development, optimization and control of baths for producing such amorphous alloys has therefore been undertaken. The results on electrodeposition of CoW-B ${ }^{8-10}, \mathrm{Ni}-\mathrm{W}-\mathrm{B}^{11}, \mathrm{Fe}-\mathrm{W}-\mathrm{B}^{12}$ and Co-Mo-B ${ }^{13}$ have already been reported from this laboratory.

\section{Experimental}

All reagents used were of analytical grade purity and deionized distilled water was used for preparation of the solutions.

A large number of experimental runs were realized to develop a suitable bath composition for electrodeposition of Ni-Mo-B amorphous alloys with desirable characteristics. ${ }^{14}$ Nickel sulfate and sodium molybdate were incorporated in the bath as source of nickel and molybdenum. The concentrations of nickel and molybdenum were kept as high as possible consistent with remaining soluble at proper mole ratio. Boron phosphate was added to the bath to provide a source of boron for creating amorphous nature to the deposit. Boron content was kept as high as possible consistent with solubility. Sodium citrate was added as complexing agents for stability of the bath. Its optimum concentration for the bath was determined experimentally. Sodium-1dodecylsulfate was added as a wetting agent to reduce hydrogen pitting. $\mathrm{pH}$ of the bath was adjusted with ammonia.

The electrodeposition was realized on a copper sheet cathode of $c a .8 .0 \mathrm{~cm}^{2}$ surface area rotated at a constant rate by EG\&G 616 rotor, using either a platinum foil of $15.36 \mathrm{~cm}^{2}$ or a platinum cylindrical gauze of $112 \mathrm{~cm}^{2}$ as anode, potentiostat Amel 555B as a source of potential and a thermostat MTA KUTESZ MD2 for controlling the bath temperature. The cathode was polished on Carbimate papers with decreasing grit size and finished on alumina powder of 1 and $0.3 \mu \mathrm{m}$. The nature of the deposit was verified by $\mathrm{X}$-ray diffraction using cobalt $\mathrm{K}$-alpha radiation. The composition of the deposit was determined by analyzing nickel as dimethyl glyoximate, ${ }^{15}$ molybdenum as lead molybdate ${ }^{15}$ and boron as methyl borate..$^{15}$ The composition of the deposit obtained by the classical methods was further confirmed by atomic absorption spectroscopy. The deposit was dissolved by digesting in minimum quantity of concentrate nitric acid and then diluted to appropriate concentration for the analysis. The concentration of nickel ${ }^{16}$ and molybdenum ${ }^{16}$ was then determined by standard methods using Varian 260B spectrometer. The content of boron was deduced by difference. Microhardness of the deposits was determined by using a pointed Vicker indenter with a load of $25 \mathrm{~g}$ and loading time of $15 \mathrm{~s}$. At least eight hardness measurements were conducted on each coating. More details of the methods and equipments used for the physicochemical determinations can be seen elsewhere. ${ }^{8}$

A large number of electrodeposition experiments were realized for optimization of the operating parameters. The optimized bath composition used in this study is as presented in Table 1. The deposition experiments were performed by using the following ranges of the operational parameters: cathode current density $75-140 \mathrm{~mA} \mathrm{~cm}{ }^{-2}$, cathode rotation $5-60 \mathrm{rpm}$ and bath temperature $25-80^{\circ} \mathrm{C}$. The deposition process was realized by putting the cathode in parallel to the platinum foil or inside the platinum cylindrical gauze anode. After every $20 \mathrm{~min}$ of the deposition the cathode was dried and weighed to analyze the results. A Mettler analytical balance with sensitivity of $0.01 \mathrm{mg}$ was used for weighing. The result reported is an average of three experiments performed under identical conditions.

Table 1. Composition of the Ni-Mo-B alloy deposition bath

\begin{tabular}{|c|c|c|c|}
\hline Compound & $\begin{array}{c}\text { Concentration } \\
\mathrm{g} \mathrm{L}^{-1}\end{array}$ & $\begin{array}{l}\text { Metal } \\
\mathrm{g} \mathrm{L}^{-1}\end{array}$ & $\begin{array}{l}\text { content } \\
\text { mol L-1 }\end{array}$ \\
\hline $\mathrm{Na}_{2} \mathrm{MoO}_{4} \cdot 2 \mathrm{H}_{2} \mathrm{O}$ & 4.23 & 1.677 & 0.017 \\
\hline $\mathrm{NiSO}_{4} 6 \mathrm{H}_{2} \mathrm{O}$ & 46.00 & 10.278 & 0.175 \\
\hline $\mathrm{BPO}_{4}$ & 7.70 & 0.787 & 0.073 \\
\hline $\mathrm{Na}_{2} \mathrm{C}_{6} \mathrm{H}_{5} \mathrm{O}_{7} \cdot 2 \mathrm{H}_{2} \mathrm{O}$ & 117.6 & & \\
\hline sodium-1-dodecylsulfate & 0.035 & & \\
\hline $\mathrm{NH}_{3}(\mathrm{aq})$ for $\mathrm{pH}$ adjustments to 9.5 & & & \\
\hline
\end{tabular}

Voltammetric experiments were performed to monitor concentration and electrochemical reactivity of metallic species in the bath. An EG\&G 273 potentiostat was used 
as the source of applied potential and as a measuring device. A $10 \mathrm{~mL}$ portion of the plating bath solution was taken in the cell each time. The $\mathrm{pH}$ of the solution was adjusted to 9.5 by $\mathrm{NH}_{4} \mathrm{OH}$. The solutions were deaerated by purified argon, and a blanket of argon was maintained over the solution during experiments. For squarewave voltammetric experiments, parameters used were: step height, $\Delta \mathrm{E}_{\mathrm{S}}=10 \mathrm{mV}$, squarewave amplitude, $\mathrm{E}_{\mathrm{SW}}=50 \mathrm{mV}$, squarewave frequency, $\mathrm{f}=100 \mathrm{~Hz}$, conditioning potential $=-0.8 \mathrm{~V}$, and conditioning time $=1 \mathrm{sec}$. An average of 10 replicates was taken.

\section{Results and Discussion}

Based on a large number of electrodeposition experiments an electrolytic bath composition presented in Table 1 was selected for further studies. ${ }^{14}$ A series of electrodeposition experiments was performed to study the effect of operating parameters on deposition of the alloy. The main operating variables are current density, temperature, agitation of the bath and anode geometry. The control of operating variables is much more important in alloy plating than in the deposition of single metal. In the case of deposition of alloys moderate changes in plating conditions may alter the composition and properties of the deposit considerably. In regular type of alloy plating systems it is expected that an increase in current density causes the content of more noble metal in the deposit to decrease; and an increase in temperature or in agitation of the bath causes the content of more noble metal to increase. But the effects of the operating variables on the induced type of codeposition, such as nickelmolybdenum alloys, are complicated and not consistent enough to be predictable.

\section{Effect of rotation of cathode}

Rotation of cathode can directly affect the composition of the alloy by reducing the thickness of cathode diffusion layer and also by causing the metal ratio of the diffusion layer to approach more closely to that of the solution in the body of the bath. The concentration of the free complexing agent in the cathode diffusion layer is also reduced by agitation, which may have a powerful effect on the potential of one or both of the metals. Also, the possibility exists that the trend of alloy composition resulting from a reduction in the concentration of free complexing agent may be opposite in sense to that resulting from an increase in the metal ion concentration of the cathode diffusion layer. Such possibility may occur in an alloy deposition system where less noble metal alone complexes with the complexing agent. This means that in baths made up with complex ions, the effects of agitation are not as predictable as those in baths made up with simple ions.

The effect of cathode rotation rate observed on efficiency of deposition of the alloy for the bath at $\mathrm{pH} 9.5$, temperature $80^{\circ} \mathrm{C}$ and cathode current density $100 \mathrm{~mA} \mathrm{~cm}^{-2}$, is demonstrated in Figure 1. It can be seen that the cathode current efficiency approaches to the highest level at $15 \mathrm{rpm}$. The trend in the efficiency change cannot be explained only by simple mass transfer to the cathode, but the explanation should include some complex reaction sequences involving a series of electron transfer steps and modification of electrode surface. The decrease observed in the current efficiency at rotation speeds higher than $15 \mathrm{rpm}$ may be ascribed to the kinetic correlation of codeposition of nickel, molybdenum and hydrogen. Molybdenum deposition is activation controlled whereas nickel and hydrogen discharges are diffusion controlled. ${ }^{17}$ It may be presumed that under the prevailing electrodeposition conditions, as the rotation speed is increased from $15 \mathrm{rpm}$, the concentration of molybdate ions within the cathode layer is also increased, formation of lower-valency molybdenum compounds thus being easier. The latter compounds block the cathode surface and consequently, the percentage of molybdenum in the coating is decreased. A black bloom arising on the cathode surface in such
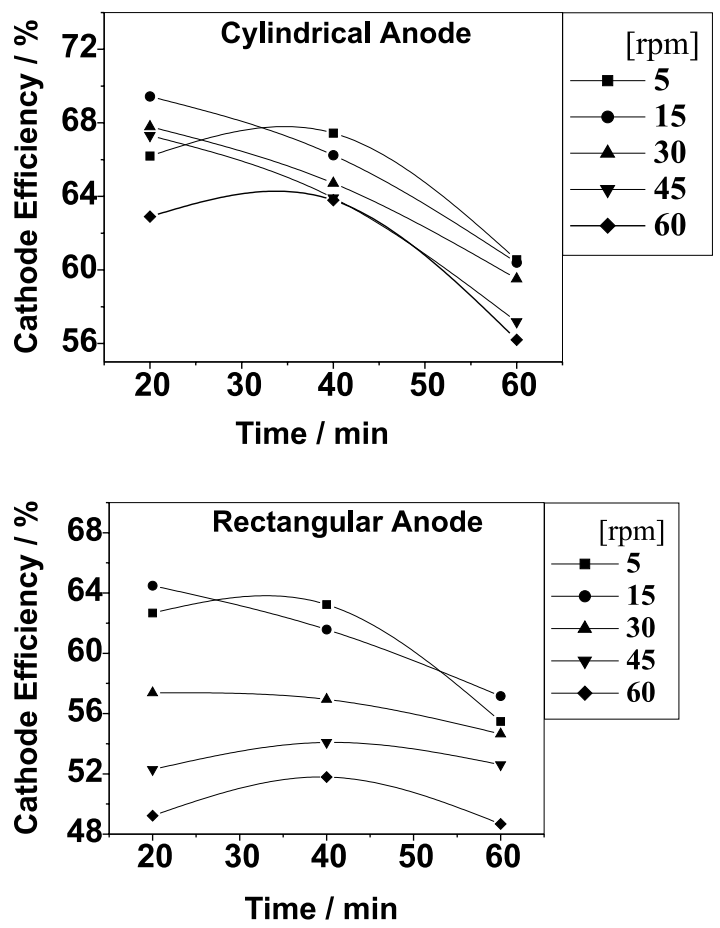

Figure 1. Effect of cathode rotation rate on cathode current efficiency. The deposition realized with bath composition as in Table 1, bath temperature $80^{\circ} \mathrm{C}$ and cathode current density $100 \mathrm{~mA} \mathrm{~cm}^{-2}$. 
conditions supports this mechanism. A similar effect was observed with increased sodium molybdate concentration in the bath. This abnormal effect, i.e. the process rate lowers with higher rotation, may also be correlated to an intermediate active product being formed during the process and taking part in indirect reactions on the electrode. The proposed stepwise reduction of molybdenum is in agreement with the observations of Chassaing et al..$^{18}$ in electrodeposition of Ni-Mo alloys.

\section{Effect of temperature}

Increase in temperature usually decreases polarization, increases concentration of metal in the cathode diffusion layer and may affect the cathode current efficiency of deposition of metals, particularly those deposited from complex ions.

A series of electrodeposition runs was performed at different temperatures ranging from $25^{\circ} \mathrm{C}$ to $80^{\circ} \mathrm{C}$. The cathode rotation rate $15 \mathrm{rpm}$ and cathode current density
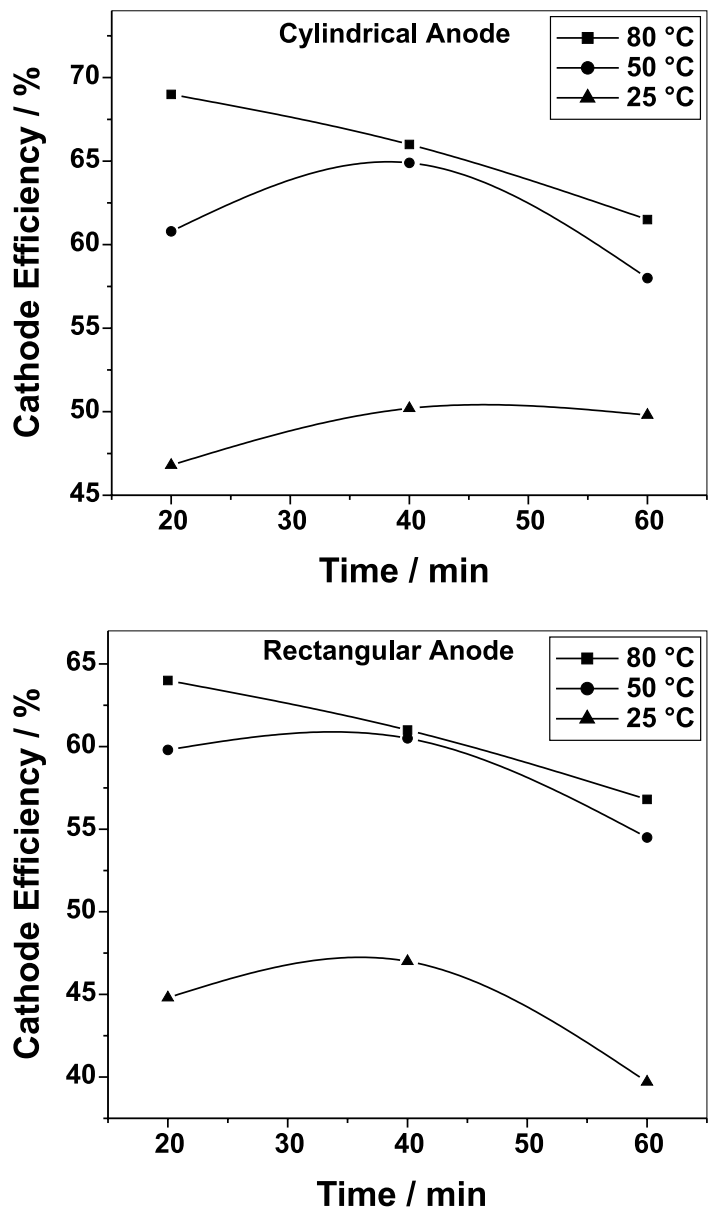

Figure 2. Effect of the bath temperature on cathode current efficiency. The deposition realized with bath composition as in Table 1, cathode current density $100 \mathrm{~mA} \mathrm{~cm}{ }^{-2}$ and cathode rotation rate 15 rpm.
$100 \mathrm{~mA} \mathrm{~cm}{ }^{-2}$ were used in this study. The variation of cathode current efficiency with temperature is demonstrated in Figure 2. It can be seen that the cathode efficiency is higher in the range of $50-80^{\circ} \mathrm{C}$. The deposit obtained at $80^{\circ} \mathrm{C}$ was found to have the best physical characteristics such as appearance and hardness.

\section{Effect of current density}

Current density is the most important of the operating variables. The behavior of regular alloy systems could be explained with a fair degree of success by diffusion theory. Unfortunately, no similar, simple explanations are available for explaining all the vagaries of the induced codeposition systems with respect to current density.

Using the cathode rotation $15 \mathrm{rpm}$ and the bath temperature $80^{\circ} \mathrm{C}$ a series of electrodeposition experiments was performed in the current density range of $20-140 \mathrm{~mA} \mathrm{~cm}^{-2}$. It can be observed in Figure 3 that the cathode current efficiency increases with increase in the current density. It was found that a good quality of the coating could be achieved at a relatively narrow range of cathode current densities. The lower range of preferred current density
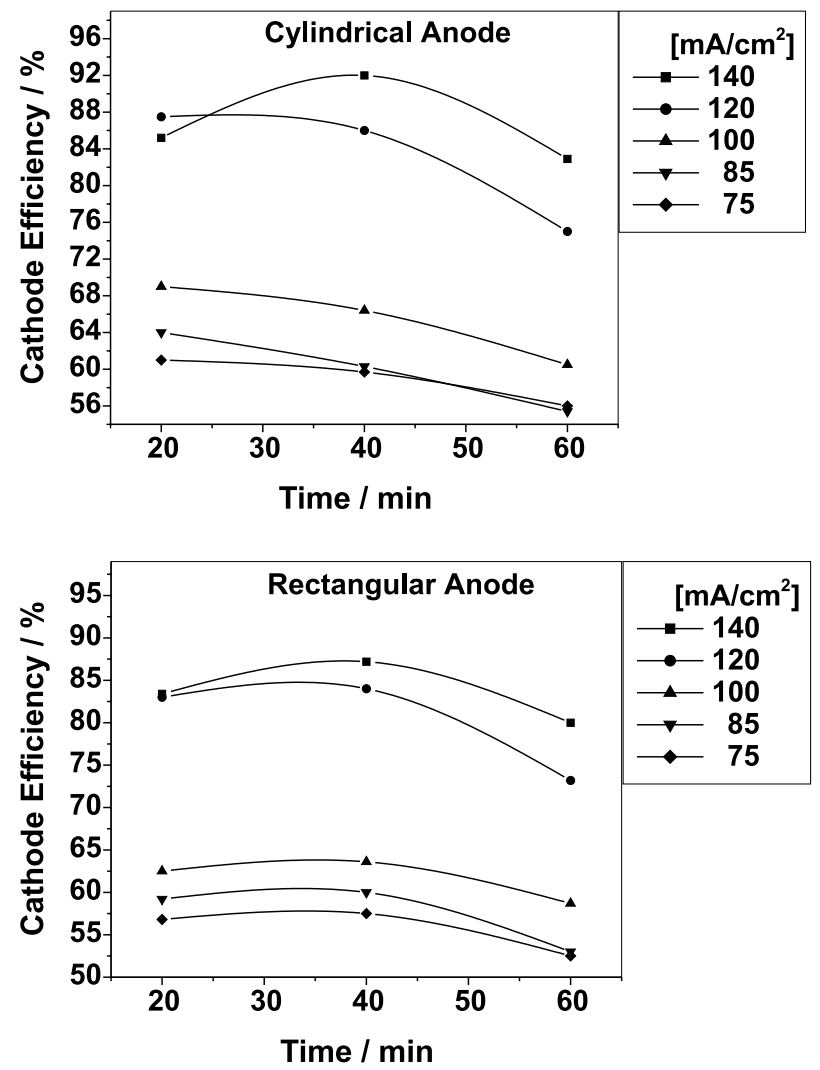

Figure 3. Effect of cathode current density on cathode current efficiency. The deposition realized with bath composition as in Table 1 , bath temperature $80^{\circ} \mathrm{C}$ and cathode rotation rate $15 \mathrm{rpm}$. 
turned out to be above the hydrogen overvoltage of the cathode and it is postulated that the nascent hydrogen may be involved in the reduction of the molybdate complex. ${ }^{18}$ The best operating current density was found to be $100 \mathrm{~mA} \mathrm{~cm}^{-2}$. Below this current, deposits tend to be dark probably due to deposition of partially reduced molybdenum oxides. Higher current density tended toward poor quality deposits.

\section{Effect of anode geometry}

Comparing the cathode current efficiencies obtained using cylindrical gauze anode with those obtained using rectangular anode, it was verified that in all the cases the bath performance increases with the cylindrical anode (Figures 1-3). This increase in performance can be ascribed to the more symmetrical distribution of the electrical field for the cathode when it is placed within the cylindrical anode.

After optimizing the operational parameters, the final electrodeposition experiments were realized to compare the performance with the two types of anode (Figure 4). Reproducibility of the results was checked at least three times for each type of anode. The results were found to be completely reproducible with a relative standard deviation of $<1 \%$. The electrodeposition was performed at $80^{\circ} \mathrm{C}$ on a copper cathode of $8.0 \mathrm{~cm}^{2}$ surface area rotating at a speed of $15 \mathrm{rpm}$ and maintained at a constant current density of $100 \mathrm{~mA} \mathrm{~cm}^{-2}$. The deposit obtained was sound and smooth. The Vickers micro-hardness of the deposit was in the range of 860-890. An X-ray diffraction scan of these alloys plated on copper substrate using cobalt $\mathrm{K}$-alpha radiation showed a poorly developed broad peak, characteristic of a partially amorphous structure (see Figure 5). The alloy deposited was having an average composition of $76 \% \mathrm{Ni}, 23 \%$ Mo and $1 \% \mathrm{~B}$. The maximum cathode current efficiency

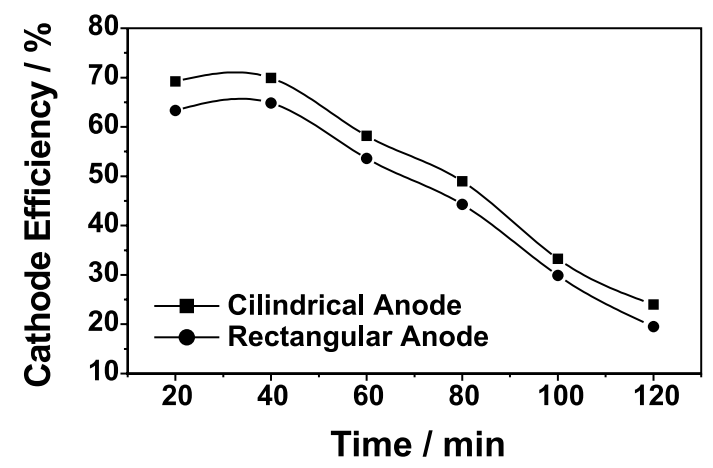

Figure 4. Effect of anode geometry on cathode current efficiency. The deposition realized with bath composition as in Table 1, bath temperature $80^{\circ} \mathrm{C}$, cathode current density $100 \mathrm{~mA} \mathrm{~cm}^{-2}$ and cathode rotation rate $15 \mathrm{rpm}$.

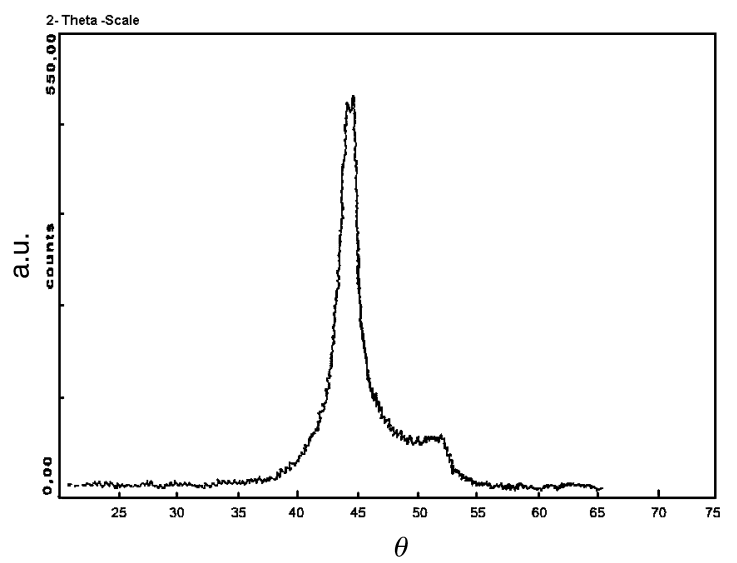

Figure 5. X-ray diffraction pattern of the alloy layer of a $0.005 \mathrm{~cm}$ thickness deposited on a copper substrate using cobalt $\mathrm{K}$-alpha radiation.

obtained was around $64 \%$ for rectangular platinum anode and $69 \%$ for platinum cylindrical gauze anode.

\section{Stability and performance of the deposition bath}

$100 \mathrm{~mL}$ of the bath presented in Table I was electrolyzed at $80^{\circ} \mathrm{C}$ for $5 \mathrm{~h}$. A copper foil of $2.50 \mathrm{~cm}^{2}$ area was used as cathode and a platinum foil of $15.36 \mathrm{~cm}^{2}$ worked as anode. It was found that during the $4 \mathrm{~h}$ of electrolysis at $100 \mathrm{~mA} \mathrm{~cm}^{-2}$ cathode current density the deposition efficiency dropped from about $64 \%$ to $31 \%$. The fall in current efficiency during the course of electrolysis should be caused mainly by decrease in Ni(II) and molybdate concentrations. It is also reported in the literature that anodic degradation of ammonia ${ }^{19,20}$ and citrate ions $^{21}$ may contribute to this fall.

It is usually assumed that, during electrolysis with positively polarized noble metal anode, the anodic reaction is simply the oxidation of water to oxygen. However, under conditions of low efficiency and large cell potentials, other oxidation processes are possible which may consume or transform components of the bath. The simplest problem is that of oxidation of metal ions, e.g. $\mathrm{Ni}$ (II) to $\mathrm{Ni}(\mathrm{III}){ }^{22}$ The organic compounds such as complexants, surfactants, brighteners and wetting agents can be oxidized in aqueous solution at potentials less positive than the potential of oxygen evolution. For example, carboxylic acid group can be oxidized to carbon dioxide with simultaneous production of radicals. ${ }^{21}$ Alcohols and aldehydes can be oxidized to various products depending on substrate and oxidation conditions. ${ }^{23,24}$ Ammonia can be oxidized at potentials lower than about $1.2 \mathrm{~V} \cdot{ }^{19,20}$ These oxidation reactions may be responsible for low stability and poor 
performance of the baths. Moreover, nickel and cobalt compounds are known to catalyze anodic processes of organic compounds, ${ }^{25}$ and to increase the overpotential for oxygen evolution. ${ }^{26}$ Thus the presence of a nickel salt in an electroplating bath in which an inert Pt-anode is used should result in a faster decomposition of citrate and ammonium ions.

Electrodeposition in the cell with anode in a separate compartment

Some electrodeposition experiments were realized on a cell with anode in a separate compartment to see if the deposition performance improves. The alloy plating experiments as described in the above paragraph were repeated by putting $\mathrm{Pt}$-anode in a compartment containing $1.0 \mathrm{~mol} \mathrm{~L}^{-1} \mathrm{Na}_{2} \mathrm{SO}_{4}$ at $\mathrm{pH} 9.5$ separated from the cathode by a glass frit. During the $4 \mathrm{~h}$ of platting the cathode current efficiency decreased from $64 \%$ to $45 \%$ in contrast to $31 \%$ for unseparated cell. This shows that separating the anodic and cathodic processes during the electroplating of the alloy is an effective method for improving the stability and efficiency of the bath.

\section{Monitoring and controlling the alloy deposition baths}

The above description shows that anodic decomposition of the bath ingredients is the main cause of its low stability. Keeping the anode in a separate compartment shows great improvement in the stability. But during the electrolysis, as time passes, the concentration of the metallic components falls due to their removal in the form of the deposit. There should be some device to monitor the concentration of these components so that they may be replenished at right moment to maintain the quality of the deposit and efficiency of the process. As the alloy deposited has a definite composition, monitoring the concentration of any one ingredient may reveal the concentration of the remaining components.

There are several methods to analyze the bath solutions. But the preferred method should be simple, rapid, capable of being readily automated, and should be applicable to the diversity of the bath problems. A squarewave voltammetric method $^{27}$ has been developed which fulfills all these requirements. By performing a series of squarewave voltammetric experiments the experimental parameters were determined. It was found that the bath solution diluted with ammonia buffer of $\mathrm{pH} 9.5$ gives a very well shaped netcurrent peak at $-1.1 \mathrm{~V}$ corresponding to $\mathrm{Ni}(\mathrm{II})$ reduction (Figure 6). The peak height is linearly related with the Ni(II) concentration (Figure 7). The results obtained show that the method is very satisfactory for monitoring the $\mathrm{Ni}$ (II) concentration even in very high speed plating baths as this technique provides results in a time scale of seconds. The process can easily be automated by coupling it with a computer. The computer may automatically control: the polarographic analyzer for realizing squarewave voltammetry; rinsing, sampling and cell drain functions; and calculation of results and then replenishment of the ingredients. ${ }^{28}$

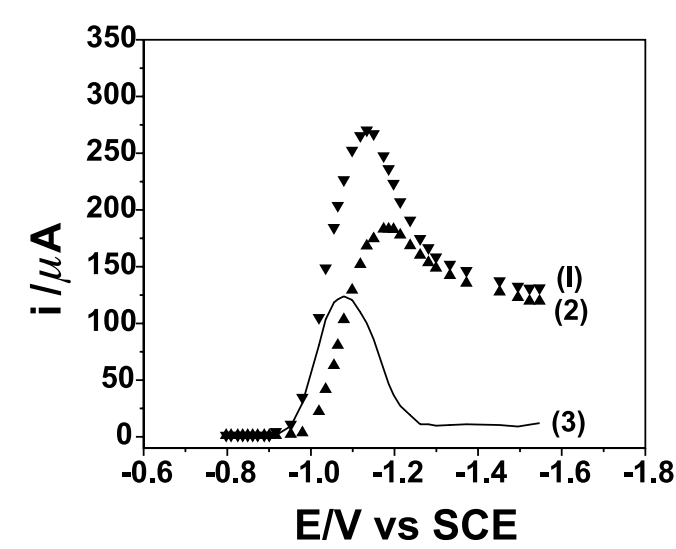

Figure 6. Squarewave voltammogram of bath solution of Table 1 at $\mathrm{pH}$ 9.5. $\Delta \mathrm{E}_{\mathrm{s}}=10 \mathrm{mV}, \mathrm{E}_{\mathrm{sw}}=50 \mathrm{mV}, \mathrm{f}=100 \mathrm{~Hz}$, conditioning potential $-0.8 \mathrm{~V}$, number of scans averaged 10. (1) forward, (2) inverse, (3) net current.

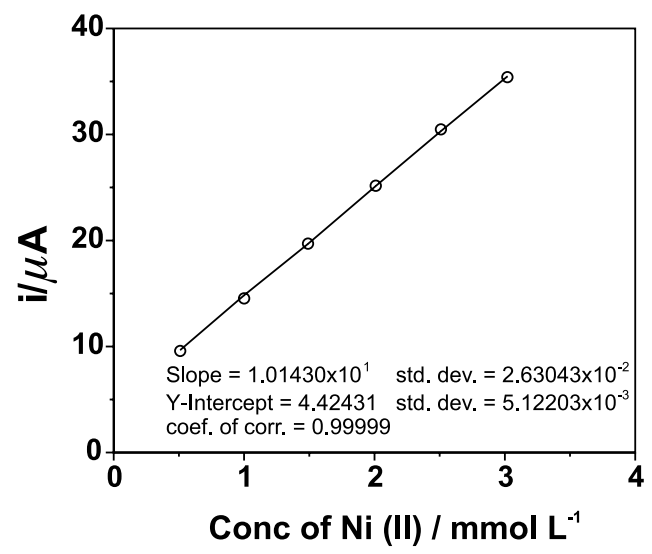

Figure 7. Concentration of $\mathrm{Ni}(\mathrm{II})$ versus squarewave net-current peak height. (O) experimental points, and (-) linear regression.

\section{Conclusion}

The most suitable values of operating parameters for the bath composition presented in Table 1 for electrodeposition of Ni-Mo-B alloy were: bath temperature $80^{\circ} \mathrm{C}$, cathode current density $100 \mathrm{~mA} \mathrm{~cm}^{-2}$ and cathode rotation speed 15 rpm and the cylindrical anode. The average composition of the alloy deposited was $76 \% \mathrm{Ni}, 23 \% \mathrm{Mo}$ and $1 \% \mathrm{~B}$. The alloy deposited was sound, thick, hard and partially 
amorphous. The maximum cathode current efficiency was found to be $69 \%$. Anodic decomposition of the bath ingredients, such as of ammonium and citrate ions, was principally responsible for degradation and aging of the bath. The stability of the bath was improved by using anode in a separate compartment. The bath composition can be monitored by squarewave voltammetric method.

\section{Acknowledgement}

The authors are grateful to CNPq, CAPES and PRH(25)/ ANP for financial assistance.

\section{References}

1. Brenner, A.; Electrodeposition of Alloys, Academic Press: New York, 1963.

2. Devis, G.L.; Gentry, C.H.R.; Mttallurgia 1956, 53, 3.

3. Holt, M.L.; Met. Finish. Sept. 1956, 48.

4. Goltz, L.N.; Kharlamov, V.N.; Zhur. Priklad. Khim. 1936, 9, 640.

5. Vaaler, L.E.; Holt, M.L.; Trans. Electrochem. Soc. 1946, 90, 43.

6. Brenner, A.; Burkhead, P.S.; Sentel, C.A.; U.S. Patent 2,653,128, 1987

7. Watanabe, T.; New Materials and New Processes 1985, 3, 307.

8. Prasad, S.; $49^{\text {rd }}$ International Congress on Metallurgy and Materials Tachnology, São Paulo, 1994.

9. Prasad, S.; Proc. Interfinish. Latino-americ., São Paulo,1997.

10. Prasad, S.; Marinho, F.A.; Metal Finishing 2002, 100 (in press).

11. Prasad, S.; Trat. Superfície 1998, 87, 32.

12. Prasad, S.; Marinho, F.A.; Silva, L.B.; J. Indian Chem. Soc. 2000, 77, 311.

13. Prasad, S.; Marinho, F.A.; Santana, F.S.M.; Braz. J. Chem. Eng. 2000, 17, 423.
14. Guimarães, T.L.; Marinho, F.A.; Prasad, S.; Anais do $11^{\circ}$ Cong. Bras. Eng. Quím., Rio de Janeiro, 1996.

15. Vogel, A.I.; A Textbook of Quantitative Inorganic Analysis, 3rd ed., Longmans: London, 1968, p. 479, 506, 479.

16. APHA; Standard Methods for the Examination of Water and Waste Water, $18^{\text {th }}$ ed., Public Health Association: Washington, 1992, p. 3.

17. Beltowska-Lehman, E.; J. Appl. Electrochem. 1990, $20,132$.

18. Chassaing, E.; Vu Kuang, K.; Wiart, R.; J. Appl. Electrochem. 1989, 18, 839 .

19. Gerisher, H.; Mauerer, A.; J. Electroanal. Chem. 1970, 25, 421.

20. Bard, A.J.; ed., Encyclopedia of Electrochemistry of Elements. Marcel Dekker: New York, 1978, v. 8, p. 411.

21. Minevski, L.V.; Adzic, R.R.; J. Appl. Electrochem. 1988, 18, 240.

22. El-Halim, A.M.A.; Khalil, R.M.; J. Appl. Electrochem. 1987, 17, 956.

23. Capon, A.; Parson, R.; J. Electroanal. Chem. 1973, 45, 205.

24. Takamura, K.; Sakamoto, S.; J. Electroanal. Chem. 1980, 113, 273.

25. Wendt, H.; Scheneider, H.; J. Appl. Electrochem. 1986, 16, 134.

26. Armstrong, R.D.; Briggs, G.W.D.; Charles, E.A.; J. Appl. Electrochem. 1988, 18, 215.

27. Osteryoung, J.; O’Dea, J.J. In Electroanalytical Chemistry -A Series of Advances; Bard, A.J., ed.; Marcel Dekker: New York, 1986, v. 14, p. 209.

28. Selk, K.; Proceedings of the $25^{\text {th }}$ Annual Meeting of the IPC, Boston, Massachusetts, April 1982.

Received: January 21, 2002 Published on the web: August 1, 2002 